\title{
Rhegmatogenous retinal detachments in pediatric vitreoretinopathies in Saudi Arabia
}

\author{
This article was published in the following Dove Press journal: \\ Clinical Ophthalmology \\ 15 April 2016 \\ Number of times this article has been viewed
}

\section{Arif $O$ Khan}

Eye Institute, Cleveland Clinic Abu Dhabi, Abu Dhabi, United Arab

Emirates
Correspondence: Arif O Khan

Eye Institute, Cleveland Clinic Abu Dhabi, PO Box I I24I2, Abu Dhabi, United Arab Emirates

Email arif.khan@mssm.edu

\section{Dear editor}

I congratulate the authors on their retrospective study of rhegmatogenous retinal detachment in patients (mostly children) diagnosed with Stickler syndrome in Saudi Arabia. ${ }^{1}$ However, I would like to point out that this work would more appropriately be considered a retrospective study of vitreoretinopathies in general rather than of Stickler syndrome specifically because a percentage of cases were likely recessive vitreoretinopathies. In my experience, children in Saudi Arabia with pediatric retinal detachment and high myopia are often labeled as having Stickler syndrome while in fact recessive vitreoretinopathies such as Knobloch syndrome ${ }^{2}$ or LRPAP1-related high myopia $^{3}$ comprise a significant percentage of cases. In addition, even when a child from Saudi Arabia truly has Stickler syndrome, it is typically a special recessive form of vitreoretinopathy from a biallelic collagen gene mutation rather than the classic autosomal dominant Stickler syndrome that is recognized worldwide and is due to a heterozygous COL2A1 mutation (unpublished data, 2004-2015).

\section{Disclosure}

The author reports no conflicts of interest or financial disclosures in this communication.

\section{References}

1. Alshahrani ST, Ghazi NG, Al-Rashaed S. Rhegmatogenous retinal detachments associated to Stickler syndrome in a tertiary eye care center in Saudi Arabia. Clin Ophthalmol. 2015;10:1-6. doi:10.2147/ OPTH.S91444. eCollection 2016. PubMed PMID: 26730175.

2. Khan AO, Aldahmesh MA, Mohamed JY, Al-Mesfer S, Alkuraya FS. The distinct ophthalmic phenotype of Knobloch syndrome in children. Br J Ophthalmol. 2012;96(6):890-895. doi:10.1136/bjophthalmol2011-301396.

3. Khan AO, Aldahmesh MA, Alkuraya FS. Clinical characterization of LRPAP1-related pediatric high myopia. Ophthalmology. 2016;123(2):434-435.

Dove Medical Press encourages responsible, free and frank academic debate. The content of the Clinical Ophthalmology 'letters to the editor' section does not necessarily represent the views of Dove Medical Press, its officers, agents, employees, related entities or the Clinical Ophthalmology editors. While all reasonable steps have been taken to confirm the content of each letter, Dove Medical Press accepts no liability in respect of the content of any letter, nor is it responsible for the content and accuracy of any letter to the editor.

Clinical Ophthalmology

\section{Publish your work in this journal}

Clinical Ophthalmology is an international, peer-reviewed journal covering all subspecialties within ophthalmology. Key topics include: Optometry; Visual science; Pharmacology and drug therapy in eye diseases; Basic Sciences; Primary and Secondary eye care; Patient Safety and Quality of Care Improvements. This journal is indexed on

\section{Dovepress}

PubMed Central and CAS, and is the official journal of The Society of Clinical Ophthalmology (SCO). The manuscript management system is completely online and includes a very quick and fair peer-review system, which is all easy to use. Visit http://www.dovepress.com/ testimonials.php to read real quotes from published authors. 